\title{
THE DYNAMICS OF HUMAN DESIRE IN BUDDHISM AND CHRISTIANITY
}

\author{
Albertus Bagus Laksana*
}

\begin{abstract}
In their struggle against the capitalist colonization of desire, Christianity and Buddhism offer similar strategies of fundamental formation or transformation of human desire. This article examines three specific features in which Christianity and Buddhism share a broad and deep resemblance in their analysis of on the dynamics of human desire and its transformation. First, both traditions identify distorted human desire as a source of bondage (or suffering), which affects the mind (intellectual), the heart (affective) and the body. Second, in terms of the strategy of liberation from this bondage, both agree that human desiring constitutes the most effective internal force available in the human makeup itself. Thus, the liberation process is not aimed at wiping out human desire but rather at channeling the very power of human desiring through a process of education whose dynamics are understood as an ascent or a journey that leads to higher (or deeper) Reality. Third, with regard to the direction of liberation, both traditions assert that this process should be directed not only toward the self but also towards others. Here the benefit for others, the virtue of caritas in Christianity and bodhicitta in Buddhism, constitutes a fundamental part of the direction of this process of formation.
\end{abstract}

Keywords: Christianity, Buddhism, desire, capitalism, bondage, transformation, caritas, bodhicitta.

Abstrak: Dalam perlawanan mereka terhadap kolonisasi hasrat oleh kapitalisme, tradisi Budhis dan Kristiani menawarkan cara-cara yang mirip untuk mendidik atau mentransformasi hasrat manusia. Artikel ini membahas tiga unsur penting yang sama dari analisis Budhisme dan Kristianitas mengenai dinamika hasrat manusia dan transformasinya. Pertama, kedua tradisi ini mengidentifikasi hasrat manusia yang rusak atau salah arah sebagai sebab dasariah dari penderitaan manusia.

* Albertus Bagus Laksana, Fakultas Teologi, Universitas Sanata Dharma, Jl. Kaliurang Km. 7, Yogyakarta.E-mail:bagus.laksana@gmail.com. 
Kerusakan hasrat ini juga mempengaruhi dimensi intelektual, afektif dan juga tubuh manusia. Kedua, perihal cara pembebasan dari penderitaan ini, kedua tradisi ini juga sepakat bahwa hasrat manusia merupakan daya internal paling efektif dalam diri manusia sendiri. Karena itu, proses pembebasan ini tidak dimaksudkan untuk membuang hasrat dari kemanusiaan, melainkan untuk menyalurkan daya hasrat ini melalui proses transformasi yang berdinamika "mendaki," sebuah perjalanan menuju Realitas yang lebih tinggi atau dalam. Ketiga, mengenai arah pembebasan ini, kedua tradisi menekankan bahwa proses ini ditujukan tidak hanya untuk diri sendiri melainkan juga sesama. Dalam hal ini, kepentingan sesama seperti diungkapkan oleh keutamaan caritas dalam Kristianitas dan bodhicitta dalam Budhisme merupakan bagian dasariah dari arah transformasi hasrat manusia itu sendiri.

Kata-kata kunci: Kristianitas, Budhisme, hasrat, kapitalisme, penderitaan, transformasi, caritas, bodhicitta.

\section{PRELIMINARY REMARKS}

When, some years ago, Francis Fukuyama told the world that human history had come to an end as had reached the furthest possible achievement, too many people regarded him more as a prophet-philosopher than as a scientist or cultural analyst. His argument in The End of History and the Last Man - that liberal capitalism and democracy constitute the peak (the end) of history because they could arguably satisfy the deepest human longing-sounded more like a prophecy than a description of facts. ${ }^{1}$ In the view of many, that supposed end seemed too glorious. However, if we take a closer look at the way capitalism is working triumphantly worldwide now, probably we have to confirm Fukuyama's analysis, albeit with sadness. Why? Because, as it appears now, the capitalist victory is a brute fact which nobody can deny. Contrary to what Fukuyama thought, however, this victory seems to have been achieved not because capitalism has proved itself to be the ultimate fulfillment of human desire, but rather

1 Francis Fukuyama, The End of History and the Last Man (New York: The Free Press, 1992). 
because through its technologies of desire, capitalism has succeeded in "manipulating" human desire according to its own agenda and interests. Thus capitalism is not a fulfillment of human desire but rather a defilement and distortion of it.

In the words of Gilles Deleuze, a noted French postmodern philosopher, this capitalist victory lies, not primarily in economic areas, but on the ontological level, as it presents itself more and more as an ensemble of technologies, skillful at molding the constitutive human power, desire. ${ }^{2}$ In this sense, capitalism has penetrated our lives far more deeply than we would normally think. It has evolved quite rapidly, from an economic system into a culture by whose value systems we unconsciously define ourselves.

I argue that this capitalist culture constitutes the most threatening challenge faced by all religions, including Christianity and Buddhism. From their very birth, Christianity and Buddhism have presented themselves as integral programs for the formation of human desire. As Nicholas Lash, the noted Cambridge theologian, rightly states, Christianity and Buddhism are "schools whose pedagogy has the twofold purpose-however differently conceived and executed in the different traditions - of weaning us from our idolatry and purifying our desire." ${ }^{\prime 3}$ In both, the concept and practice of liberation, understood in its deepest and funda-mental sense as the process of the transformation of human desire, is central and decisive. Religion cannot wean people from any form of idolatry unless it transforms the mechanism of human desiring. Desire is, precisely, a force that can easily drive people away from God or the Absolute One. Being aware of the nature of this problem, Christianity and Buddhism develop various ways to deal with human desire.

In this article I want to show that in their mission to mold human desire, Christianity and Buddhism share many things in common,

2 See Daniel Bell, Jr., Liberation Theology After the End of History: A Refusal to Cease Suffering (London: Routledge, 2001), p. 9.

3 Nicholas Lash, The Beginning and the End of 'Religion' (Cambridge: Cambridge University Press, 1996), p. 21. 
notwithstanding some fundamental differences. I will not argue from a very general point of view, but from a rather close analysis of a selected number of Christian and Buddhist theologians and thinkers. On the Christian side, my choice falls to three great theologians: Gregory of Nyssa, Augustine, and Bonaventure. ${ }^{4}$ On the Buddhist side, I draw insights from Tibetan Buddhism, more specifically, the Dogzen tradition and Tantric Buddhism.

Within the larger context of their dealing with human desire, I want to examine three more specific features on which Christianity and Buddhism share a broad and deep resemblance of analysis. The first is their analysis of the source or root of human bondage (unhappiness, sinfulness, or unliberatedness). I argue that in both traditions, distorted human desire, which deeply affects the mind (intellectual), the heart (affective) and the body, is identified as the source of bondage. The second point, a logical sequence to the first, is their analysis of the strategy of liberation. Although both traditions locate the root of human bondage in the human incapability to mold desire, both agree that human desiring constitutes the most effective internal force available in the human make-up itself, and that the process of human liberation will not be effective unless it uses this force skillfully. For both, the liberation process is by no means aimed at wiping out human desire but rather at channeling the power of human desiring through a delicate process of education or formation. Both traditions also understand this process as an ascent, a journey that leads human beings on the dynamic path that goes higher and higher (or deeper and deeper). In other words, the education of desire should be seen as something very similar to any other education. It takes time and moves in a progressive track. For Christianity, the ultimate goal is union with God whereas for Buddhism, nirvana or enlightenment.

The third point, closely related to the second, has to do with the direction of the process of liberation. Both traditions are very clear in

4 I will only consult certain works of each of these theologians. I select Gregory's Life of Moses and Homilies on the Song of Songs, Augustine's Confessions and City of God, and Bonaventure's The Journey of Mind to God. 
their assertion that this process should be directed not only towards our own self but also toward others. In this regard, one can argue that the benefit for others (caritas in Christianity and bodhicitta in Buddhism) constitutes a fundamental element in the overall direction in this very process of liberation.

In the first part of this essay, I elaborate on these three points from the perspective of Christian tradition as it is expressed in the writings of Gregory of Nyssa (c.335-c.395), Augustine (354-430) and Bonaventure (1217-1274). The second part will be devoted entirely to the exposition of Buddhism (Tibetan) in response to these three themes. In making some connections between the two traditions, I employ a method of broad analogy. Thus, comparisons will be made, but on a broader level. For the sake of focus and brevity, I will also pay almost exclusive attention to the similarities between these two traditions, without necessarily assuming that the differences between the two are not real.

\section{EDUCATION OF DESIRE IN THE CHRISTIAN TRADITION}

As previously mentioned, this part deals with the idea of the education or transformation of desire in the Christian tradition, drawing insights from the relevant works of three great theologians from the Patristic period to the Medieval period, namely, Gregory of Nyssa (335395), Augustine (354-430), and Bonaventure (1217-1274). My main reason for this choice is that these three great Christian theologians portray Christian life as a journey to God, marked by the struggle to educate desire in a dynamic process both God's agency and human effort are involved. As we see, this understanding of the dynamics of Christian life is very fitting for our subject matter. Later, in Part II, we will examine further how this understanding also corresponds to the Buddhist conception of the human journey toward liberation.

\section{Christian Analysis of Human Bondage}

Let us begin with Gregory of Nyssa. Through his various theological writings, Gregory of Nyssa explores the centrality of human desire in 
the search for God. For example, he interprets the Song of Songs as a strategy that attracts and inflames the desire to long for God. ${ }^{5}$ For him, this desire is the basis of the human ascent into God. But, as he rightly notes, the biggest problem in every human struggle for union with God lies in the temptation of the soul, through the mechanism of desiring, to seek ultimacy in what is not God. Thus, human desire is a double-edged sword: it can drive human persons to God as the Ultimate Good, but it can easily entice them to mistake creatures for God. Human sinfulness is precisely this proclivity for moving away from God through the seemingly unmanageable mechanism of desiring.

In the life of St Augustine we find a perfect example of how this double-edged sword becomes a lifelong struggle. In the beginning of his Confessions, Augustine beautifully summarizes the ascending nature of human desire for God, "You stir man to take pleasure in praising you, because you have made us for yourself, and our hearts are restless until they rest in you." 6 But, as we move to the story of his boyhood, we see how his human desire - or what he refers to the human heart's "restlessness" - leads him not to God but to various vanities. He says, "I abandoned you to pursue the lowest things of your creation." ${ }^{7}$ One of the most enduring personal struggles for Augustine is what Joyce Schuld calls "performative vulnerabilities." ${ }^{8}$ Human desiring is vulnerable because it is susceptible to manipulation and corruption which can eventually lead human beings to a place where they find no true happiness. It is even more vulnerable, as Augustine testifies, as it fails to perform what we really want to do. In his Confessions, Augustine tells us how difficult it is for him to mold his desire in accordance with the goal of life he has already

5 See Martin Laird, “Under Solomon's Tutelage: The Education of Desire in the Homilies on the Song of Songs," in Re-thinking Gregory of Nyssa, edited by Sarah Coakley (Blackwell: Malden, 2003), pp. $1 \mathrm{ff}$.

6 Augustine, Confessions, trans. Owen Chadwick (Oxford University Press, 1998), I. 1.

7 Augustine, Confessions, I. 21.

8 J. Joyce Schuld, Foucault and Augustine: Reconsidering Power and Love (Notre Dame: University of Notre Dame Press, 2003), pp. 83 ff. 
discovered, that is, a "beautiful existence," God himself. Often it becomes an impasse, as he laments:

I was astonished to find that already I loved you, not a phantom surrogate for you. But I was not stable in the enjoyment of my God. I was caught up to you by your beauty and quickly torn away from you by my weight. With a groan I crashed into inferior things. This weight was my sexual habit. ${ }^{9}$

It is extremely important to note that although in this quotation sexual desire is explicitly mentioned, it would be a grave error to conclude that for Augustine, sexual concupiscence constitutes the only hindrance in his search for union with God. For him, sexual desire is not the root of his performative vulnerabilities, but only a symptom of a more foundational problem with governing human desire. ${ }^{10}$ It is true that sexual cravings led Augustine away quite easily from his pursuit of the true Beauty. But, he never views sexual yearning itself-something that can be located within the sheer biology of human body - as the root problem. Human wandering away from God is caused by a mechanism of desire that is more integral, as it touches the whole person, not only the body but also the mind and the heart. Augustine often refers to his misuse of his own intellectual gifts in his intellectual passion for literature and philosophy. After his conversion, he considers his Manichean period with so much disgust precisely because it constitutes a far more fundamental refusal of the true belief in God than his sexual misconduct. Thus, for Augustine, human desire should be understood as a force that configures individuals as a whole: their minds and intellects, their bodily cravings, their movements of heart, their wills and memories.

We move now to Bonaventure, a great Fransciscan theologian. In his theological understanding, desire is a multilayered word. ${ }^{11}$ He uses

9 Augustine, Confessions, VII. 23.

10 Joyce Schuld, Foucault and Augustine, p. 85.

11 See, for example, Stephen Brown's comment on Bonaventure's notion of desire. Bonaventure, The Journey of the Mind to God, trans. Stephen Brown (Indianapolis: Hackett Pub. Co., 1993), footnote no. 16. 
it in a number of ways. In the first place, he understands desire as a fundamental force in the human soul which drives the soul toward God. In his prologue to The Journey of the Mind to God, he says:

For no one is in any way disposed for divine contemplations that lead to spiritual transports unless, like Daniel, he is also a man of desires. Now, such desires are enkindled in us in two ways, to wit, through the outcry of prayer, which makes one sigh from anguish of heart, and through the refulgence of speculation by which the mind most directly and intensely turns itself toward the rays of light. ${ }^{12}$

But, why does Bonaventure speak of the need for prayer and the refulgence of speculation? It is because here he refers to the corrupted human condition after the fall or original sin. According to him, prior to original sin, the original disposition of human nature was fit for the contemplation of God. During this period, pleasure and desire already existed but in pure forms, in the "paradise of pleasure" ${ }^{13}$ But, the socalled original sin distorted this natural mechanism of human desire in a twofold manner: now ignorance distorts our mind and concupiscence our flesh. So, the need for prayer and speculation arises as a result of original $\sin$.

We see that Bonaventure's analysis of human bondage takes into account the (distorted) mechanism of human desire. For him, the struggle of human beings after the fall is to bring their very desire, which he sometimes refers to as "the natural power of the soul" back to the right track. This process of bringing desire back to its original destiny can be called "the education of desire." For this purpose, Bonaventure offers some educational strategies: prayer, justice (leading a just life), meditation,

12 Bonaventure, The Journey, Prologue, p. 3. In chapter III, Bonaventure refers to desire more specifically as a part of the human elective faculty. For him, as for Augustine before him, the individual human soul has three principal faculties: memory, intellect, and will (the elective faculty). In this understanding, human desire is only one element of three which make up the elective faculty (the other two being counsel and judgment). But, even in this specific understanding, human desire functions as an internal force, which drives the soul to God as the highest Good. See, The Journey, III. 4, emphasis added.

13 Bonaventure, The Journey, I. 7. 
and contemplation. ${ }^{14}$ We should not fail to notice that, for Bonaventure, our distorted desire affects both our mind (heart) and flesh.

\section{Christian Analysis of the Strategy of Liberation}

Our preceding analysis shows that in Christian tradition, human desire, understood in its integral sense, is the place where things go wrong, where human longing for God as the Ultimate One is led astray. Now, we proceed with the second point in our inquiry, that is, developing the idea that for Christianity the process in which human beings are liberated from the bondage of distorted desire should be understood as a process of education of desire itself. Far from banishing desire from the individual person, this education employs some strategies that utilize the force of desire to reach union with God. Furthermore, according to our selected Christian theologians, this process takes the shape of an ascent to God. This means that there are several steps by which individuals educate their desire, with the help of God's grace, to come to ever higher knowledge of and union with God.

In his Life of Moses, Gregory of Nyssa envisions the human ascent to God as an infinite process, which consists in making progress in the life of virtue. ${ }^{15}$ Thus, he connects union with God to a virtuous life. No union with God is possible without a virtuous life. For him, the life of virtue is ultimately our participation in God's life. Since God is without limit, the progressive journey in the life of virtue also has no limit. Aided by his mastery of ancient biblical hermeneutics, he takes the life story of Moses as an example of a human journey toward a perfect life.

It is worth noting how Gregory treats human desire in this process. On the one hand, he makes it clear that along this arduous journey, some expressions of human desire should be purified and cleansed as a prerequisite for the next step, as seen in the story of Moses and the

14 Bonaventure, The Journey. I. 8.

15 Gregory of Nyssa, The Life of Moses, trans. Abraham Malherbe and Everett Ferguson (Toronto: Paulist Press, 1978). 
Israelites. ${ }^{16}$ But, on the other hand, he refers to human desire as a force which drives the soul to ever higher steps toward God. In this context, he describes human desire as something that knows no final satisfaction. ${ }^{17}$ In his spiritual interpretation of Moses' experience of God, he portrays the dynamic of human desire as a dynamic that makes the human person always thirst for something behind the perceived image, to be able to see the true Beauty, face to face. This desire for God will never be satisfied because "the true sight of God consists in this, that the one who looks up to God never ceases in that desire."18 His conclusion runs as follows:

This truly is the vision of God: never to be satisfied in the desire to see him. But one must always, by looking at what he can see, rekindle his desire to see more. Thus, no limit would interrupt growth in the ascent to God, since no limit to the Good can be found nor is the increasing desire for the Good brought to an end because it is satisfied. ${ }^{19}$

Thus, it becomes clear that for Gregory human desire should be educated so as to be able to sustain the movement of the soul to the ever higher step toward God.

In Gregory's understanding, the spiritual ascent to God consists of several steps. This ascent has to be understood as a process of purification of desire toward the mystical experience of God's incomprehensibility. ${ }^{20}$ Key to this process of purification is the readiness of the soul to look to "him who suffered the passion for us." ${ }^{21}$ Here, Gregory refers to the

16 For example, he writes, "Those who pass through the mystical water in baptism must put to death in the water the whole phalanx of evil-such as covetousness, unbridled desire, rapacious thinking, the passion of conceit and arrogance, wild impulse, wrath, anger, malice, envy, and all such things. Since the passions naturally pursue our nature, we must put to death in the water both the base movements of the mind and the acts which issue from them." See Gregory of Nyssa, The Life of Moses, II, 125 (126-129).

17 Gregory of Nyssa, The Life of Moses, II, p. 230.

18 Gregory of Nyssa, The Life of Moses, p. 233.

19 Gregory of Nyssa, The Life of Moses, p. 239, emphasis added.

20 Gregory of Nyssa, The Life of Moses, p. 169.

21 Gregory of Nyssa, The Life of Moses, p. 273. 
power and meaning of Christ's cross. For him, looking to the cross also means the ability to control the unruly side of human desire. Gregory is aware that the redemptive grace brought about by Christ's cross does indeed prevent evil power from prevailing against the faithful, but it does not wipe out human desire. Seen from our previous analysis of Gregory's notion of desire, this last statement can be easily understood. Since human desire constitutes a force which drives individuals in their ever higher search for union with God, this desire should never vanish because this search for God has no end. But, as desire can be unruly and misleading, Gregory tells his readers to draw strength from the cross of Christ and to always have fear of God's commandment. ${ }^{22}$ The peak, but not the end point, of the human spiritual ascent to God, for Gregory, consists in the mystical experience of God's incomprehensibility as symbolized by Moses' experience of God in the darkness.

Unlike Gregory's The Life of Moses, Augustine's Confessions does not explicitly teach the readers the ways to embark on the journey into God. But, Augustine himself hopes that his Confessions will eventually lead his brothers and sisters to God. ${ }^{23}$ His hope is well founded since his way of narrating his life journey, his dramatic conversion in the Confessions, follows the pattern of an ascent to God. Quite surprisingly, his peak experience did not occur in his baptism into the Catholic faith, but during the spiritual vision he and his mother experienced at Ostia. This vision began as Augustine and Monica talked about the eternal life of the saints. Given the importance of this vision, his account of that event is worth quoting at length here:

Our minds were lifted up by an ardent affection towards eternal being itself. Step by step we climbed beyond all corporeal objects and the heaven itself, where sun, moon, and stars shed light on the earth. We ascended

22 Gregory of Nyssa, The Life of Moses, p. 277.

23 See book X of his Confessions where he expresses his hope that the account of his life will edify others. He writes, "Stir up the heart when people read and hear the confessions of my past wickedness, which you have forgiven and covered up to grant me happiness in yourself, transforming my soul by faith and your sacrament" $(X, 4)$. 
even further by internal reflection and dialogue and wonder at your works, and we entered our minds. We moved beyond them.... And while we talked and panted after it, we touched it in some small degree by a moment of total concentration of the heart. ${ }^{24}$

This rich quotation displays many important elements. First, as Augustine sees it, his mystical experience occurs as an ascent to God, "the eternal being itself." Secondly, he explicitly refers to the role of the mind ("internal reflection and dialogue") in reaching God, although at some point, the mind itself would be transcended. Thirdly, this ascent is driven, and to some extent sustained, by desire, "ardent affection", and "total concentration of the heart."

In itself, this entire account of Augustine's mystical vision speaks of what a spiritual ascent to God might look like. It starts with the desire to know more deeply some spiritual truths or realities. Through the grace of $\mathrm{God}^{25}$ the mind climbs higher and higher, sustained by an ardent desire to move closer to God. In this process, the mind enters itself, but at some point, the mind should be surpassed.

But, we should note that this vision would have never happened without the previous education of desire. Augustine writes that the vision at Ostia happened only after he and his mother reached the conclusion that "the pleasure of the bodily senses, however delightful in the radiant light of this physical world, is seen by comparison with the life of eternity to be not even worth considering." ${ }^{26}$ Indeed, for Augustine, it took many years of anguishing struggle to come to this kind of conclusion. As Joyce Schuld points out, Augustine is a man always fascinated and obsessed by beauty. For him, the experience of beauty sensualizes his intellect, heart, and body. Later on he finds this experience problematic, since often "he

24 Augustine, Confessions, IX, 24, emphasis added.

25 Throughout his Confessions, Augustine keeps telling us about the power of God's grace in his life. Often he refers to God's grace as "God's gift" (donum Dei), a central concept in his theology. For him, every good thing that happens in his life is God's gift.

26 Augustine, Confessions, IX. 24. 
allows himself to be so caught up in the resplendence of the world that he becomes unable to enjoy through these created blessings God's glory." 27 Thus, Augustine's problem with his desire for sensual beauty is whether he is capable of referring this desire to the love of God. His education of desire consists in training his desiring mechanism so as to be able to enjoy created beauty only in relation to God, the Creator. Augustine does not seem interested in banishing the impulse of desire. His concern is to reconfigure and transform the force of desire for the purpose of his spiritual journey. In this sense, we can speak of the purification of desire.

With Bonaventure, the idea of spiritual ascent to God finds its systematic treatment. The Journey is meant to be a guide for those who aspire to embark on a series of progressive illuminations "by which the soul is disposed, as by certain grades or steps, to pass over to peace through the ecstatic transports of Christian wisdom." 28 There are six steps in this ascending journey into God. These six steps are divided into three pairs of steps. The first pair consists in contemplating God outside us, that is, through and in the vestiges of God in the visible (created) world. In the second pair of steps, we contemplate God within us, namely, through contemplation of our soul itself as the image of God and through consideration of the presence of God in the soul. The third pair refers to the contemplation of God above us through the act of knowing God as pure being and God as The Good (God as self-communicating love in the life of the triune God). ${ }^{29}$

Apart from its being more systematic, Bonaventure's notion of this spiritual ascent is not so different from that of Augustine. In fact, he was very much influenced by Augustine in several important points. Similar to Augustine's approach, his ascent starts from the created world, to the mind itself, and at last, surpassing the mind and human under-

27 Joyce Schuld, Foucault and Augustine, p. 90.

28 Bonaventure, The Journey, Prologue, p. 3.

29 See Stephen Brown's introduction to Bonaventure's The Journey of the Mind to God, pp. xvi-xviii. The concepts of outside us, within us, and above us are Bonaventure's own words. See Bonaventure, The Journey, V.1. and VII.1. 
standing, arrives at the highest step: to know God's attributes as pure being and the Good.

As we have seen above, Bonaventure emphasizes the importance of human desire to begin the journey: one should be a "wo/man of desires." But, it turns out that this same desire is still very much needed during the whole journey. In the first two steps, human desiring works through the mechanism of bodily senses which inform the interior senses, "in order to see the supreme power, wisdom, and goodness of Creator which shines forth in created things." 30 So, at this point, human desire should help the soul to be able to see the beauty and wonder of creation and then, through or in it, should enable the soul to see God.

Before we move to the role of desire in the higher stages, we should remember that for Bonaventure in his original Latin, the word mens (genitive: mentis) does not refer to the intellect (intellectus) but to "the intellectual energy" of the human person. Thus, when this word is translated into English as "mind" (his original Latin title is Itinerarium Mentis in Deum which is typically translated into English as The Journey of the Mind to God), it almost loses its original meaning as a dynamic energy of the human. As we noted above in our treatment of Augustine's notion of desire (which affects the intellect, heart and body of the person), this "intellectual energy" can be seen as part of the larger human desiring force. Consequently, even when Bonaventure does not use the word "desire," he does not rule out the presence of its energy in its intellectual dimension. However, it seems clear that he uses many words which are closely related to the affective side of human desire. For example, in the third and fourth steps where he discusses the soul's turning towards itself, to the mind as the image of God, he speaks about the transformation of the soul brought about by the three theological virtues, namely, faith, hope and love in Jesus Christ. For him, this transformation is experienced on the level of affections, that is, the recovery of the internal senses'

30 Bonaventure, The Journey, III. 10. 
ability to desire and taste the most beautiful. ${ }^{31}$ This transformation results in "the abundance of devotion, the exuberance of admiration, and the superabundance of exultation" experienced by the soul as it contemplates God. Only after this transformation, the soul can find God who is present in the soul itself.

Bonaventure continues to use affective words such as "devotion," "admiration," "amazement," and "exultation" to depict the experience of the soul in its encounter with God in the two highest stages. For him, this lofty spiritual encounter can only be experienced with the full force of human desire. After reaching the highest step (sixth), the soul's desire passes over entirely to God. ${ }^{32}$

\section{Analysis of the Direction (Caritas)}

As we come to the third point in our inquiry, we examine the direction of the spiritual ascent into God as understood by Gregory, Augustine and Bonaventure. I argue that according to these three theologians, our spiritual ascent should be directed to the attainment of the love of God which, in turn, ought to be expressed in loving service to our neighbors. Only in this movement would the perfection of the self be achieved.

In Gregory's The Life of Moses we see that Moses' ascent into God occurs as he offers himself gradually to God for the benefit of the liberation of his fellow Israelites. Moses' encounter with God always results in the call to service. The higher Moses' ascent to God goes, the greater service he is called to perform for his people. On the final pages of this work, Gregory expresses the final goal of the human ascent into

31 We should notice that in the third step Bonaventure also refers to "desire" as a specific part of the human elective faculty which moves the person to God as the highest Good. See, The Journey, III. 4. Furthermore, it is interesting that Bonaventure, in the fourth chapter, makes an allusion to the Canticle of Canticles, one of the Solomonic books, which has been traditionally regarded as containing a pedagogy of human desire.

32 Bonaventure, The Journey, VII. 1. 
God: to be God's servant and friend. ${ }^{33}$ In line with the Gospel's core message, there will be no other way to be God's servant and friend except through loving God and loving one's human neighbor.

In Augustine's view, one's neighbor with God constitutes the most fundamental relationship. In the City of God, he makes it clear that once human capacity to love is directed away from God and toward the self, it fuels the desire to control others. So, for him, human love for God is the guarantee for human love for others. Self-love (amor sui) always carries with it the danger of generating libido dominandi, the carnal desire to dominate others. For Augustine, the root of this libido is superbia, namely, the desire to acquire as one's own possession the unlimited power of the divine Creator. ${ }^{34}$ Ultimately only the love for God can eradicate this superbia. In this logic we see that directing human desire wholly to God will not diminish the human capacity to love others, but will ensure and strengthen that very capacity. Thus, for Augustine, mystical union with God ultimately has a fundamental impact on each human person's relationships with others.

For Bonaventure, the ultimate goal of the ascent is peace, wisdom (as the experiential knowledge of God), and charity. Thus, we can say that the six steps of the ascent eventually lead one to God as Self-Giving Love (caritas). The highest step (sixth) consists in contemplating the Trinity as the Good itself, whose fundamental nature is self-diffusing, self-giving, and self-communicating. ${ }^{35}$ Understood in this sense, this mystical experience should never be separated from the practice of self-giving to others, as practiced by St. Francis of Assisi, the example set forth by St. Bonaventure in the beginning of his treatise.

33 Gregory of Nyssa, The Life of Moses, II, pp. 317, 320.

34 See Joyce Schuld, Foucault and Augustine, p. 10.

35 See Bonaventure, The Journey, VII. 2. 


\section{EDUCATION OF DESIRE IN THE (TIBETAN) BUDDHIST TRADITION}

After laying out the three features of the Christian formation of human desiring in the previous part, in what follows I will present the corresponding Buddhist analyses. Using a method of broad analogy, I basically argue that Buddhism shares much of the Christian analysis of human bondage as rooted in distorted human desiring, its strategy of liberation through transformation of human desire, and its sense of the overall process of liberation where the benefit of others forms a constitutive part.

\section{Buddhist Analysis of Human Bondage}

Although it expresses it differently ways, Buddhism agrees with the Christian tradition that (distorted) human desire is the force that drives humans into samsaric experience. In Buddhism, the understanding and practice of liberation takes as its starting point the sheer reality of suffering (samsara). Capturing the second noble Truth of the Buddha, Jamgon Kongtrul, a Tibetan Buddhist scholar, explains that the source of this suffering is "disturbing emotions and actions." 36 This is so because they cloud and confuse the mind. In the same book, The Great Path, Kongtrul speaks of the three poisons which arise in connection with three objects: "compulsive attachment arises for objects that are pleasant or useful, aversion arises for objects that are unpleasant or harmful, and stupidity or indifference for other objects." ${ }^{37}$ In this context we can say that in Buddhism, disturbing emotions, attachments, aversion, stupidity and indifference belong to the general idea of (distorted) human desire. Geshe Kelsang Gyatso, another Tibetan Buddhist master, confirms this conclusion when, commenting on Chandrakirti's Madhyamakavatara, he says:

36 See Jamgon Kongtrul, The Great Path of Awakening: The Classic Guide to Using The Mahayana Buddhist Slogans to Tame the Mind and Awaken the Heart, trans. Ken McLeod (Boston \& London: Sambhala, 2000), p. 14.

37 Jamgon Kongtrul, The Great Path of Awakening, p. 15. 
Living beings have many desires - desires that arise through the force of delusions such as attachment and hatred, desires that arise through the force of virtuous minds such as faith and compassion, desires that arise through the force of imprints in the mind, and many others. Just one living being has countless desires. Some desires are inferior, others middling, and others superior. ${ }^{38}$

In my opinion, Gyatso's differentiation of desires helps us to understand two things. First, disturbing emotions and actions as the cause of samsara form only part of human desire. It is the lowest (impure and distorted) level of human desire. Second, human desire is an internal force which continues to affect human persons along the journey of liberation. As we can see, this understanding of desire is strikingly similar to the general Christian understanding, since it identifies desire not only as a carnal force operating in the body, but also as an intellectual (spiritual) and affective power which affects the mind and the heart of the human person. When we identify "disturbing emotions and actions" as the cause of suffering, we should keep in mind that it is only an element of a much larger force in the human person, an element which needs to be educated throughout the whole process of liberation.

This kind of desire impedes liberation and causes samsara because it prevents the mind from coming to a correct understanding of the nature of reality. As we know, the ultimate liberation in Buddhism lies in the attainment of enlightenment of the mind (the Buddhahood). This enlightenment consists in coming to see and realize the true nature of mind and reality, thus overcoming ignorance and the ego-cherishing patterns of the mind. As we will see later, the control over the lowest level of desire is not a sufficient condition for enlightenment, although it is a necessary one.

\section{Buddhist Analysis of the Strategy of Liberation}

According to the Buddhist worldview, humans as samsaric beings are living in the realm of desire. This means that "we are afflicted with 
gross desirous attachment." ${ }^{39}$ However, this does not mean that the door to liberation is closed. In the Mahayana tradition, for example, there is a way in which this desire is turned into virtue. In the Great Path, Jamgon Kongtrul gives us a method for this transformation of desire through a kind of meditation prayer which goes as follows:

May every bit of every sentient being's attachment be contained in this attachment of mine. May all sentient beings have the seed of virtue of being free of attachment. May this attachment of mine contain all their disturbing emotions and, until they attain buddhahood, may they be free of such disturbing emotions. ${ }^{40}$

Displaying faithfully the characteristic of the Mahayana tradition, this text speaks of the power of desire, even the disturbing desire, in helping people along the path of liberation. According to this teaching, the attachment of someone can absorb the disturbing emotions of all other sentient beings.

The use of the power of desire in the process of liberating transformation is most palpable in the Tantric tradition of Buddhism. ${ }^{41}$ Lama Thubten Yeshe, a Tibetan tantric teacher, boldly states that "the basic energy involved in this profound process of tantric transformation is the energy of our own desires." 42 The three kinds of desires mentioned earlier can be used as vehicles for enlightenment. In Lama Yeshe's view, the Tantric practice of liberation is based on the fact that our present lives

(London: Tharpa Publication, 1995), pp. 423-424.

39 Geshe Kelsang Gyatso, Ocean of Nectar, p. 100.

40 Jamgon Kongtrul, The Great Path of Awakening, p. 15.

41 In terms of the actual practice of meditation to attain enlightenment, this tantric tradition is not so far different from other traditions, such as Dzogchen. The Dzogchen path has three main elements: View, Meditation, and Action. To attain the correct view of reality, Dzogchen also speaks about the need for purification and renunciation of desire. But, generally speaking, I argue that the Tantric tradition speaks more about the role of desire in the whole process of enlightenment. This is the only reason for my selection of this tradition in this article.

42 Lama Thubten Yeshe, Introduction to Tantra: The Transformation of Desire (Boston: Wisdom Publications, 2001), p. 5. 
are inseparably linked with desire, and that the tremendous energy of desire should not be wasted, but used for life transformation.

For many, perhaps, all these ideas sound too good to be true. How is it possible that the energy of lust, for example, can be turned into a spiritual energy? The logic of tantra relies on a very simple fact about the basic nature of the experience of pleasure. Basically, all experiences of pleasure share a common feature in that they all are felt to be satisfying. Based on such a simple notion, it is possible that "our experience of ordinary pleasure can be used as the resource for attaining supremely pleasurable experience of totality or enlightenment." 43 But, this process requires a skillful use of the energy of desire, training desire to be able to experience true pleasure on the road to a full illumination. In his explanation of this skill, Lama Yeshe emphasizes the role of the mind. One should be able to keep the mind continuously in as happy and peaceful a condition as possible. This means, among other things, trying to stop the habitual patterns of grasping and of clinging to the ego. By developing ever deeper levels of understanding, we would be able to control the whole energy of our desire and to eventually enjoy higher forms of happiness and bliss. ${ }^{44}$ With the methods of tantra, this energy of desire, which normally narrows and distorts our vision through a habitual pattern of grasping and which results in a certain kind of attachment, is transformed into a light and blissful wisdom.

In the practice of Tantra, the main method of attaining this transformation is meditation. However, to do the highest level of mediation (the three-kaya meditation) one has to fulfill some prerequisites. In a sense, this journey of transformation is an ascent to complete enlightenment, not very unlike the Christian idea of the human journey into God. The major prerequisites for the practice of Tantra (commonly called the three main aspects of the sutra vehicle to enlightenment) are renunciation, the dedicated heart of bodhichitta, and the correct view of emptiness. ${ }^{45}$

43 Lama Thubten Yeshe, Introduction to Tantra, pp. 9-10.

44 Lama Thubten Yeshe, Introduction to Tantra, p. 12.

45 Lama Thubten Yeshe, Introduction to Tantra, p. 39. 
The idea of renunciation here is not the same as rejection. Rather, it consists in educating human sensory desire to be interested in realizing its unlimited and completely liberated potential. This means liberating human desire from its preoccupation with grasping at pleasure. In order to achieve true renunciation, one should have a deep understanding that such grasping only leads ultimately to dissatisfaction and pain. As we have seen, Augustine makes the same point, that is, that one should learn from the experience of dissatisfaction with sensory pleasures (their transitory nature) that, in order to to arrive at true pleasure, one should go higher, to taste the beauty of the Creator.

The second prerequisite, the opening of our hearts to others (bodhicitta), means "that, having created a certain atmosphere of positive energy within yourself, you determine to share this happiness with others as much as possible." ${ }^{46}$ I will treat this point at some length later, but it should be pointed out now that in the Mahayana tradition, bodhicitta (loving kindness) is at the same time a prerequisite and fruit of enlightenment. In this regard, The Great Path is filled with specific methods of meditation to attain this loving kindness. ${ }^{47}$

The third prerequisite, cultivation of the correct view, constitutes the backbone of Buddhist philosophy. For Lama Gyatso, "correct view means the wisdom that clearly realizes the actual way in which we and all other phenomena exist." 48 This wisdom entails the ability to see the emptiness of reality outside and inside us (against the ego-grasping pattern of the mind), our non-self-existence and the illusory nature of phenomena.

46 Lama Thubten Yeshe, Introduction to Tantra, p. 47.

47 According to The Great Path, "there are no methods to effect this attainment (of buddhahood) other than those which rely on two forms of meditations: relative bodhicitta, which is training the mind in love and compassion, and ultimate bodhicitta, which is resting evenly in a nondiscursive state free from conceptual elaborations." Jamgon Kongtrul, The Great Path of Awakening, p. 5.

48 Lama Thubten Yeshe, Introduction to Tantra, p. 57. 
These three qualities of the mind will equip the practitioner with sufficient ground to go to the higher steps. But, in the Tantric practice, before moving to the three-kaya meditation, there is a special meditation is to do: the guru yoga meditation. The chief function of this meditation is to enable the practitioner to be inspired and strengthened by the process of unification (yoga) of oneself with the guru (teacher). Through this process, the positive energy (positive energy of desire) of the guru will take seed in the practitioner, meeting with the inner energy and wisdom of the practitioner (inner guru) and thus creating a huge accumulation of energy sufficient to embark on the highest step of Tantric practice.

The entire practice of tantric meditation is based on a fundamental notion that the nucleus of each human being, each person's essential nature, is something divine and pure. Therefore, Tantric meditation is ultimately meant to realize this divine nature. In order to understand the highest Yogatantra meditation practice, we should note its philosophical conception of the human mind and body. According to the Tantric tradition, the human mind and body, apart from their gross level of existence, also exist on a subtle level. This subtle body is called "vajra body" (vajra means indestructible). This body is pervaded by myriads of channels through which flows the energy winds (prana) and drops (bindu) that are the source of the bliss so vital to highest Tantric practice. Coming into contact with the body means realizing the divine nature within and emerging as a deity. This process entails a focusing of energy into a single most important channel or point in the vajra body (the heart cakra). This complicated step, which does not need to be explained in detail here, results in a complete transformation: our gross mind's way of perceiving is transformed into the original mind.

The peak of this journey of the mind occurs with the achievement of the truth body (dharmakaya), enjoyment body (sambhogakaya), and emanation body (nirmanakaya). These three bodies are the bodies of a buddha, the enlightened one. Of the relationship among these three, Lama Yeshe writes, "The darmakaya is the unlimited and unobstructed 
mind of an enlightened being while the remaining bodies are the two levels on which this mind manifests itself in order to benefit others." ${ }^{49}$ In short, the experience of these three bodies constitutes the experience of a total enlightenment. The end result of this process is that one emerges as a deity with three qualities: one will be able to recognize the appearance of oneself and of all other beings as deities; one will be able to place the mind in an inseparable relationship with nondual wisdom; and one will be able to experience everything with great bliss. ${ }^{50}$ We see that this final stage is a complete transformation of desire: human desire is still there, but transformed into divine desire as it is able to experience all things in bliss and utmost joy.

\section{Buddhist Analysis of the Direction of Enlightenment (Benefiting Others)}

For some, the Buddhist spiritual path might appear to be concerned only with the practitioner's own enlightenment. In fact, this impression is far from true. The road to enlightenment is filled, from its very start to its finish, with concern for others. For example, we have seen the centrality of bodhicitta (loving kindness and compassion) in the whole process. In the Mahayana tradition, relative bodhicitta is the motivation, condition and the fruit of enlightenment. Sogyal Rinpoche tries to define this extremely rich term thus:

It is not simply a sense of sympathy or caring for the person suffering, not simply a warmth of heart toward the person before you, or a sharp clarity of recognition of their needs and pain, it is also a sustained and practical determination to do whatever is possible and necessary to help alleviate their suffering. ${ }^{51}$

Without this relative bodhicitta, there is no way of attaining absolute bodhicitta (enlightenment); as Shantideva insists, "One who does not completely exchange his happiness for the suffering of others surely does

49 Lama Thubten Yeshe, Introduction to Tantra, p. 104.

50 Lama Thubten Yeshe, Introduction to Tantra, p. 125.

51 Sogyal Rinpoche, The Tibetan Book of Living and Dying (San Francisco: HarperSanFrancisco, 1993), p. 187. 
not achieve Buddhahood." 52 Echoing Jesus' saying in the Gospel, Shantideva adds, "Without forsaking one's own self, one cannot avoid suffering, just as without avoiding fire one cannot avoid being burned. Therefore, in order to alleviate my own suffering and to alleviate the suffering of others, I give myself up to others and I accept others as my own self.. ${ }^{53}$ Understood this way, bodhicitta constitutes a supreme way of being totally compassionate for others. This compassion is inclusive as it embraces, not just human beings, but all sentient beings. Listening to Shantideva's words, we cannot fail to notice the echo of the understanding of caritas as God's self-giving quality in Christian theology.

Mahayana Buddhism has a special meditation practice that functions to help practitioners to attain relative bodhicitta. In The Great Path, Jamgon Kongtrul asks them to meditate upon their own mothers whose loving attention they cannot fail to acknowledge and whose suffering they cannot ignore. After gaining a sense of real compassion for their mothers, the practitioners are asked to widen their horizon of compassion so as to include all sentient beings who have been a mother to them in the sense that these beings have helped them in many unknowable ways. ${ }^{54}$ This meditation will go on with several other figures, with a single view to generating an intense feeling of compassion. ${ }^{55}$ We can say that bodhicitta meditation is actually an effort to channel the energy of desire within each human person in the direction of limitless compassion. Imagine how powerful this energy would be if millions of people succeeded in doing this.

52 Shantideva, A Guide to the Bodhisattva Way of Life, trans. Vesna A. Wallace and Allan Wallace (Ithaca: Snow Lion Publications, 1997), pp. 106, 131.

53 Shantideva, A Guide to the Bodhisattva Way of Life, pp. 135-136.

54 To understand this point better, it is helpful to recall that Buddhism believes in the fundamental interconnectedness or interdependence among all things.

55 There are two categories of figures whom one should meditate upon during this meditation. The first are those who will be easily helpful in generating compassion, such as friends, spouses, relatives, the poor, etc. The second are those who will be more difficult, such as, enemies, demons, people who hurt the practitioner, etc. See Jamgon Kongtrul, The Great Path of Awakening, p. 13. 
Buddhist concern for others can also be seen through the final horizon of enlightenment, that is, returning back to the world of action with some new personal and interpersonal qualities. In The Great Path, there are some practical instructions which will result in the enhancement of some basic human qualities, such as patience, joy, self-control so as not to offend others, forgiveness, humility, etc. ${ }^{56}$ An enlightened person would be an extremely loving person.

\section{CONCLUSION}

By way of conclusion, I want to return to our initial goal in relation to Nicholas Lash's understanding of religious traditions as schools of human formation. My argument in this article is that Buddhism and Christianity do present themselves as schools of human formation. In this regard, one of the most basic insights of this article is that this formation takes human desire seriously as a force in which both problems and solutions can be found. Indeed, the twofold purpose of religious traditions - weaning us from idolatry and purifying our desire-should be understood as a single problem. They go together. We cannot maintain our fidelity to God unless we manage to purify our desire. Once we let our desire run wild, the road to idolatry is wide open. On the contrary, if we are able, to a certain extent, to be faithful to God, purifying our desire would be the by-product. As Augustine noted some centuries ago, our relationship with God is the most basic one, as it will affect our whole life, including our mechanism of desiring.

However, as Augustine knew all too well, both our faith and our desire are fragile and vulnerable. In my opinion, this human fragility gives rise to the constant need for religious traditions as formation programs. As this article has shown in a very modest manner, Buddhism and Christianity deal with this fragility not with a sense of helplessness, but with a hopeful determination, expressed in some concrete strategies. Based on the belief that human desire, no matter how fragile it is, offers

56 Jamgon Kongtrul, The Great Path of Awakening, pp. 27-41. 
a tremendous force, they develop some paths for the education of desire. They put these paths in the context of a human journey to God (for Christianity) or toward enlightenment (for Buddhism). Thus, they set the agenda of weaning us from idolatry or of purifying our desire as the goal of this education. We see how they treat these two aspects as a unified whole.

In the beginning of this essay, I singled out the challenge of a capitalist or neo-liberal culture as the most horrendous threat faced by religions today. In my opinion, it is by no means an exaggeration, if we understand capitalism primarily as a molding of desire. Indeed, the basis of its operation lies not so much in the economic realm but at the level of human desire. In short, capitalism works so well because it is capable of molding human desire in a way that best suits its interests. Precisely in the face of this capitalist colonization of desire, Lash's remarks about the twofold purpose of every religious tradition appear to be so urgently needed. For Christianity and Buddhism, capitalist culture forms a competing program of human formation the aim of which is to foster all kinds of idolatry served by a distorted mechanism of human desire.

Along this line, our explorations of Christian and Buddhist traditions, hopefully, help us see that Christianity and Buddhism do offer some plausible alternatives to the reigning and colonializing culture of capitalism. I have attempted to show that this plausibility lies in the fact that both traditions place considerable emphasis on the problem of human desire, an area where the battle against the excesses of capitalism occurs. From a Christian perspective, this alternative can be seen as a retrieval of its rich tradition. For instance, when liberation theology began to appear in the late 1960s, its main agenda was to fight against the oppression caused, in the final analysis, by capitalist structures of power. For this purpose, liberation theologians continue to retrieve some forgotten aspects of Christian tradition. However, despite its richness and originality, liberation theology tends to neglect one important aspect of Christian tradition, namely, its program for the formation of human 
desire. As a result, its strategy in the battle against capitalism has been somewhat marked by a kind of political resistance grounded in theological belief. Our present age has shown that this political side of capitalism might not be the real locus of its strength and victory. Put in this larger context, the basic insights of this article can be viewed as a retrieval of Christian tradition, which will provide us with some fresh alternatives in our struggle against capitalist culture. ${ }^{57}$

From the Buddhist side, our discussion will hopefully help us to clarify that Buddhism is not an exotic spiritual product from the East that will satisfy people driven by a capitalist desire to consume everything. Behind the phenomenon of continuous interest in Buddhism in the West, there is always a strong tendency to "reify" Buddhism, to treat it merely as a product. In this context, Buddhism will always be in danger of being colonized and impoverished. Over against this backdrop, I have attempted to present Buddhism as a challenge and antidote to the capitalist way of molding human desire. Far from being merely a product for capitalist consumption, Buddhism presents itself as a radically different program of human formation. It claims to transform the fundamental mechanism of human desire. Presented this way, both Buddhism and Christianity offer some extremely rich strategies in our efforts to subvert the process of human bankruptcy under a capitalist culture.

\section{REREFENCES}

Augustine, Confessions. Translated by Owen Chadwick. Oxford: Oxford University Press, 1998.

Bell, Jr., Daniel. Liberation Theology After the End of History: A Refusal to Cease Suffering. London: Routledge, 2001.

Bonaventure. The Journey of the Mind to God. Translated by Stephen Brown. Indianapolis: Hackett Publishing Co., 1993.

57 One of my reasons for choosing Gregory of Nyssa, Augustine and Bonaventure is that these theologians represent the older traditions of theological thought within Christianity. For the modern mind, it seems that their ideas are outdated. In liberation theology, for example, these theologians are almost nonexistent. In this context, exploring their theology may be seen as retrieving some older but forgotten traditions in Christian theology. 
Fukuyama, Francis. The End of History and the Last Man. New York: The Free Press, 1992.

Gregory of Nyssa. The Life of Moses. Translated by Abraham Malherbe and Everett Ferguson. Toronto: Paulist Press, 1978.

Gyatso, Geshe Kelsang. Ocean of Nectar: Wisdom and Compassion in Mahayana Buddhism. London: Tharpa Publication, 1995.

Kongtrul, Jamgon. The Great Path of Awakening: The Classic Guide to Using The Mahayana Buddhist Slogans to Tame the Mind and Awaken the Heart. Translated by Ken McLeod. Boston \& London: Sambhala, 2000.

Laird, Martin. “Under Solomon's Tutelage: The Education of Desire in the Homilies on the Song of Songs." In Re-thinking Gregory of Nyssa, edited by Sarah Coakley. Blackwell: Malden, 2003, pp. 507-525.

Lash, Nicholas. The Beginning and the End of 'Religion.' Cambridge: Cambridge University Press, 1996.

Rinpoche, Sogyal. The Tibetan Book of Living and Dying. San Francisco: HarperSanFrancisco, 1993.

Shantideva. A Guide to the Bodhisattva Way of Life. Translated by Vesna A. Wallace and Allan Wallace. Ithaca: Snow Lion Publications, 1997.

Schuld, J. Joyce. Foucault and Augustine: Reconsidering Power and Love. Notre Dame: University of Notre Dame Press, 2003.

Thubten Yeshe, Lama. Introduction to Tantra: The Transformation of Desire. Boston: Wisdom Publications, 2001. 